The Israeli Journal of Aquaculture - Bamidgeh, IIC:63.2011.620, 7 pages

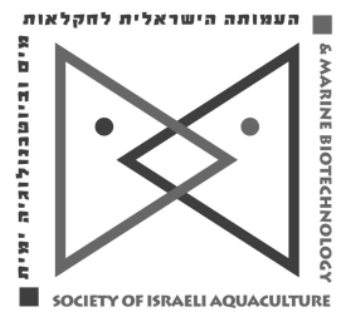

The IJA appears exclusively as a peer-reviewed on-line open access journal at http://www.siamb.org.il

Sale of IJA papers is strictly forbidden.

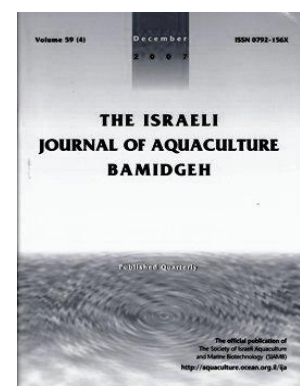

\title{
Evaluation of Autotrophic and Heterotrophic Microcosm- based Systems on the Production Response of Litopenaeus vannamei Intensively Nursed without Artemia and with Zero Water Exchange
}

\author{
M.J. Becerra-Dórame ${ }^{1}$, L.R. Martínez-Córdova ${ }^{*}$, M. Martínez- \\ Porchas $^{2}$, J.A. Lopez-Elías ${ }^{1}$ \\ ${ }^{1}$ Departamento de Investigación Científicas y Tecnológicas de la \\ Universidad de Sonora, Blvd. Colosio s/n, Building 7G, Hermosillo, Sonora, \\ 83000 Mexico \\ ${ }^{2}$ Centro de Investigaciones en Alimentación y Desarrollo A.C., Km 0.6 \\ Carretera a La Victoria, Hermosillo, Sonora, México
}

(Received 12.8.10, Accepted 23.10.10)

Key words: shrimp nursery, autotrophic system, heterotrophic system, zero water exchange

\begin{abstract}
An experiment was conducted for 28 days to evaluate the productive response of the Pacific white shrimp (Litopenaeus vannamei) postlarvae, intensively nursed in autotrophic or heterotrophic microcosm-based treatments, without Artemia and zero water exchange. The autotrophic system was based on the promotion of microalgae as the main primary producers. The heterotrophic system was based on the promotion of bacteria as the main primary producers. The control was fed a conventional diet. Bioflocs and biofilms were used to promote biota in the autotrophic and heterotrophic systems. There were no differences in temperature, salinity, or DO among treatments. The chlorophyll a concentration and microalgae density were much greater in the control and autotrophic system than in the heterotrophic. The concentration of heterotrophic bacteria was significantly higher in the heterotrophic than in the autotrophic system and control. Individual weight gain was higher in the control $(81 \pm 2 \mathrm{mg})$ and heterotrophic $(77 \pm 8 \mathrm{mg}$ ) treatments than in the autotrophic $(58 \pm 10 \mathrm{mg})$ but survival was better in the autotrophic (86\%) than control $(77 \%)$ and heterotrophic (76\%) treatments. Final biomass was statistically similar in all treatments, as well as the feed conversion ratio which ranged from 0.65 (heterotrophic) to 0.69 (autotrophic). The increased natural productivity caused a positive productive response in the shrimp postlarvae. Such strategies can be an adequate alternative when Artemia is unavailable.
\end{abstract}

* Corresponding author. Tel.: +52-662-2592169, e-mail: Imtz@guaymas.uson.mx 


\section{Introduction}

Shrimp aquaculture in Latin America and Asia followed an explosive development during the last decades. However, it is still an expensive activity due to the high investment needed in construction, supplies, labor, and machinery in the different phases of activity. Postlarvae supply is one of the biggest expenses, being around $10 \%$ of the total operative costs. The challenge of worldwide hatcheries is to offer shrimp farmers the quantity and quality of postlarvae they need and to have a sustainable activity. In that sense, scientific research focuses on obtaining high survival and quality of postlarvae at the lowest possible cost and with the lowest environmental impact.

One of the most important concerns is the feed and feeding of organisms. During the end of the hatchery stage and the beginning of the nursery, shrimp are fed live feed, mostly Artemia nauplii. However, this live feed is expensive and its quality is not always adequate. Attempts have been made to substitute Artemia by less expensive feed sources with similar nutritional value. Microalgae and microorganisms can be used as natural feeds in aquaculture. For instance, diatoms play an important role in shrimp larval and postlarval development (Muller-Feuga, 2005) and shrimp feeding and nutrition can be improved by greater inclusion of biota (including microorganisms) in shrimp ponds (Avnimelech, 1999). Heterotrophic organisms in bioflocs that use ammonium nitrogen produced within the system by the excretion of farmed and associated organisms contribute to the improvement of water quality (Avnimelech, 1999). Microbial biomass attached to detritus, bioflocs, or biofilms may have adequate nutritional composition (Quadros-Seiffert and Martinez-Cordova, 2006; Kuhn et al., 2010) and play an important role in shrimp nutrition at different stages of development (Ballester et al., 2010).

Some microorganisms attached to biofilms and/or bioflocs, particularly autotrophic and heterotrophic bacteria, not only contribute to the improvement of water quality in intensive systems (Thompson et al., 2000; Ebeling et al., 2006; Samocha et al., 2007), but also can support an important proportion of the growth of shrimp (Avnimelech, 1999; Ballester et al., 2003; Burford et al., 2004a; Wasielesky et al, 2006). In Brazil, microorganisms attached to biofilms or bioflocs have been successfully used in shrimp ponds or enclosures, achieving better production than on traditional farms while maintaining adequate water quality in the culture system as well as in the effluents (Ballester et al., 2007).

The aim of the present study was to evaluate autotrophic and heterotrophic microcosm-based systems on the productive response of the Pacific white shrimp, Litopenaeus vannamei, intensively nursed without Artemia and with zero water exchange.

\section{Materials and Methods}

The study was conducted over 28 days at the Centro de Investigaciones Biológicas del Noroeste (CIBNOR) in Guaymas, Sonora, Mexico. A single factor and haphazardly experimental design with three replicates per treatment was performed. Two treatments and a control were evaluated: an autotrophic treatment based on the promotion of microalgae as the main primary producers by the use of nitrogen and phosphorous fertilizer and substrates; a heterotrophic treatment based on the promotion of bacteria as the main primary producers by the use of carbon sources and substrates; and the control, a traditional system in which microalgae or bacteria were not promoted by the use of carbon sources or substrates. Nine plastic tanks (120 I operative volume) were used as experimental units (microcosms). Six were placed on a metal structure in which the three units corresponding to the autotrophic treatment and the three corresponding to the control were covered with a plastic mesh to allow moderate exposure to sun light. The three remaining units corresponding to the heterotrophic system were covered with the same plastic mesh, but placed beneath the metal structure, i.e., in its shadow, to prevent direct sunlight and proliferation of microalgae.

The tanks were filled with filtered marine water and fertilized 15 days before stocking. The autotrophic and heterotrophic tanks were provided with a substrate for the attachment of microalgae and microorganisms, respectively. The substrates consisted of 
a plastic mesh $\left(0.5 \mathrm{~m}^{2}\right)$ vertically suspended from a PVC tube. The heterotrophic units were supplied $25 \mathrm{~g}$ wheat bran once a week as a substrate for the formation of bioflocs and $100 \mathrm{~g}$ molasses at the beginning and during the trial to maintain a $\mathrm{C}: \mathrm{N}$ ratio around 20:1 (Ballester et al., 2007, 2010). The autotrophic and control tanks received an agricultural fertilizer (urea + ammonium phosphate) at the beginning and during the trial to maintain an $\mathrm{N}: \mathrm{P}$ ratio around $10: 1$ and a $\mathrm{C}: \mathrm{N}$ ratio around $4: 1$. Water was not exchanged during the trial for any of the treatments, however, water lost by evaporation was replaced weekly by fresh water (previously aerated and dechlorinated).

Each unit was stocked with 900 postlarvae of 1-day-old white shrimp $\left(\mathrm{PL}_{1}\right)$ at a density corresponding to 7500 organisms $/ \mathrm{m}^{3}$. Constant aeration was supplied by a 2-hp blower, through 1/8-plastic tubing and air stones. From the fifth day to the end of the trial, postlarvae were fed a formulated feed (Camaronina $40 \%$ crude protein, Purina, Mexico) at a rate of $8 \%$ of the total biomass.

Temperature, salinity, $\mathrm{pH}$, dissolved oxygen, total ammonia nitrogen (TAN), and chlorophyll a were recorded daily with of a multi-parameter sensor YSI 6600 (Yellow Springs, $\mathrm{OH}$ ). The microalgae and bacteria concentrations were calculated once a week by methods described by Ballester et al. (2010). The biological composition of the biofilm was examined on the last day by scraping a surface of $10 \mathrm{~cm}^{2}$ of the artificial substrates of each unit as per Burford et al. (2004b).

Once a week, 30 postlarvae were haphazardly sampled from each unit and weighed in a digital balance (Sartorius ${ }^{\circledR}$ ). Survival was estimated considering a mortality rate of around $1 \%$ per week according to the criterion of commercial laboratories. Biomass was calculated by the measured weight and estimated survival. The feeding rate was determined as $8 \%$ of the estimated biomass, supplied twice a day. Survival and biomass were calculated at the end of the trial. The feed conversion ratio (FCR) was calculated as the total dry weight of feed supplied/final wet shrimp biomass. The specific growth rate (SGR) was calculated as $\left.100\left(\ln _{\text {final wt }}-\ln _{\text {initial wt }}\right) / T_{1}-T_{2}\right)$.

A parametric one-way ANOVA was used to analyze production parameters, after confirming normality and homocedasticity. Tukey test was performed to compare and rank means from the two treatments and the control. Water quality parameters were analyzed by performing repeated measures ANOVA. A significance level of $a=0.05$ was considered.

\section{Results}

Mean temperature varied $29.8-31^{\circ} \mathrm{C}$, being slightly lower in the heterotrophic treatment but not significantly different from the autotrophic or control treatments (Table 1). Mean dissolved oxygen levels were high and did not differ between treatments. Likewise, there were no differences in total ammonia nitrogen $\left(\mathrm{NH}_{3}{ }^{+} \mathrm{NH}_{4}\right)$. There was a large difference in chlorophyll a concentration between the heterotrophic treatment and the others, similar to the microalgae concentration. Bacteria in the water were significantly more abundant in the heterotrophic treatment $\left(1.8 \times 10^{5}\right.$ cells $\left./ \mathrm{ml}\right)$ than in the autotrophic and control treatments $\left(<1 \times 10^{3}\right.$ cells $/ \mathrm{ml})$. The main taxonomic groups attached to the artificial substrates were cyanobacteria $\left(2.1 \times 10^{4} / \mathrm{cm}^{2}\right)$ and diatoms in the autotrophic system, and

Table 1. Water quality, free living microalgae, growth, and food conversion ratio during nursing of Litopenaeus vannamei in autotrophic, heterotrophic, and control systems.

\begin{tabular}{lrrr}
\hline & \multicolumn{3}{c}{ System } \\
\hline & Control & Autotrophic & Heterotrophic \\
\hline Water quality & \multicolumn{3}{c}{} \\
\hline Temperature $\left({ }^{\circ} \mathrm{C}\right)$ & $31.0 \pm 1.3$ & $31.1 \pm 1.6$ & $29.8 \pm 1.2$ \\
Salinity $(\mathrm{ppt})$ & $37.1 \pm 1.3^{\mathrm{ab}}$ & $37.3 \pm 1.0^{\mathrm{a}}$ & $35.8 \pm 0.6^{\mathrm{b}}$ \\
DO $(\mathrm{mg} / \mathrm{l})$ & $6.4 \pm 3.1$ & $6.8 \pm 3.7$ & $5.9 \pm 2.9$ \\
Chlorophyll a $\left(\mathrm{mg} / \mathrm{m}^{3}\right)$ & $407.2 \pm 179.1^{\mathrm{a}}$ & $527.5 \pm 155.6^{\mathrm{a}}$ & $17.9 \pm 8.1^{\mathrm{b}}$ \\
pH & $8.0-8.3^{\mathrm{a}}$ & $7.9-8.2^{\mathrm{a}}$ & $7.6-7.8^{\mathrm{b}}$ \\
\hline Microalgae communities $(\mathrm{cells} / \mathrm{ml})$ & & \\
\hline Cyanobacteria $\left(\times 10^{6}\right)$ & $3.22 \pm 0.18^{\mathrm{a}}$ & $3.34 \pm 0.19^{\mathrm{a}}$ & $0.02 \pm 0.004^{\mathrm{b}}$ \\
Diatoms $\left(\times 10^{4}\right)$ & $10.3 \pm 1.3^{\mathrm{a}}$ & $11.3 \pm 1.1^{\mathrm{b}}$ & - \\
\hline Growth & & & \\
\hline Initial wt $(\mathrm{mg})$ & $15 \pm 2$ & $15 \pm 1$ & $16 \pm 2$ \\
Final wt $(\mathrm{mg})$ & $96 \pm 6^{\mathrm{a}}$ & $72 \pm 11^{\mathrm{b}}$ & $93 \pm 6^{\mathrm{a}}$ \\
Wt gain (mg) & $81 \pm 2^{\mathrm{a}}$ & $58 \pm 10^{\mathrm{b}}$ & $77 \pm 8^{\mathrm{a}}$ \\
Final biomass $\left(\mathrm{g} / \mathrm{m}^{3}\right)$ & $547.5 \pm 73.3$ & $484.5 \pm 52.2$ & $504.0 \pm 56.6$ \\
SGR $(\% / \mathrm{day})$ & $6.79 \pm 0.58^{\mathrm{a}}$ & $5.59 \pm 1.04^{\mathrm{b}}$ & $6.22 \pm 0.64^{\mathrm{b}}$ \\
Survival $(\%)$ & $77^{\mathrm{a}}$ & $86^{\mathrm{b}}$ & $76^{\mathrm{a}}$ \\
FCR & $0.67 \pm 0.09$ & $0.69 \pm 0.06$ & $0.65 \pm 0.05$ \\
\hline
\end{tabular}


heterotrophic bacteria and filamentous cyanobacteria in the heterotrophic system $\left(2.5 \times 10^{5} / \mathrm{cm}^{2}\right)$.

Growth was more accelerated in the control and heterotrophic treatments than in the autotrophic treatment (Fig 1). By the end of the culture, the weight gain was statistically similar in the control and heterotrophic treatments, and $42 \%$ and $34 \%$ respectively higher than in the autotrophic treatment. Despite the higher weight gains in these treatments, there were no significant differences in biomass between treatments because of the better survival in the autotrophic treatment. The feed conversion ratio was similar in all treatments.

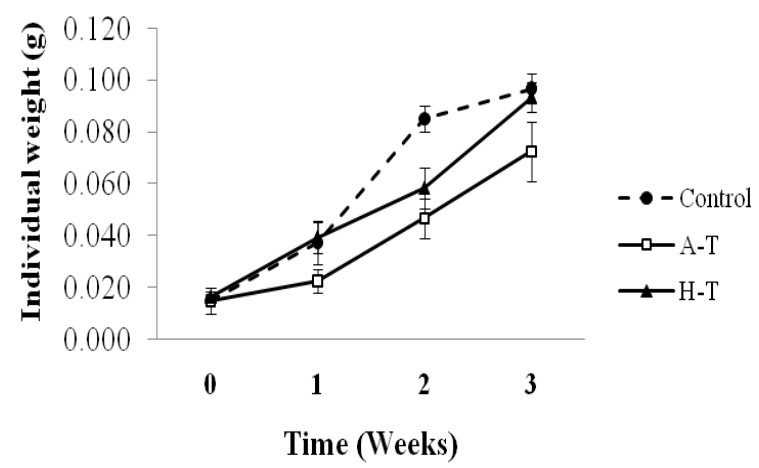

Fig. 1. Growth of Litopenaeus vannamei postlarvae in the autotrophic $(A-T)$, heterotrophic $(\mathrm{H}-\mathrm{T})$, and control systems.

\section{Discussion}

The structural and management differences of the evaluated treatments, such as light exposure, presence or absence of substrates (mesh and wheat bran), and fertilization, affected salinity, $\mathrm{pH}$, chlorophyll a concentration, microalgae, and bacteria density. Despite differences in the salinity levels due to different rates of evaporation above and below the metal structure, all values were within the ranges found in commercial farms and hatcheries.

The enormous differences in chlorophyll a concentration and microalgae density in the control and autotrophic systems, compared to the heterotrophic, were expected since, in the first two, phytoplankton was promoted by adequate inorganic fertilization and exposure to sunlight, while in the heterotrophic system, inorganic fertilizer was not used and the exposure to sunlight was limited. The chlorophyll a level and microalgae density in the autotrophic system and control were much greater than those reported for shrimp nursery, pre-grown, and grow-out systems (Ballester et al., 2010), probably because the zero water exchange impeded the drainage of nutrients. The higher $\mathrm{pH}$ in those two systems may be related to greater phytoplankton production since, during photosynthesis, microalgae intake $\mathrm{CO}_{2}$ from the water column, causing a decrease in $\mathrm{pH}$ $\left(\mathrm{CO}_{2}+\mathrm{H}_{2} \mathrm{O}=\mathrm{HCO}_{3}^{-}+\mathrm{H}^{+}\right)$.

The productive response of postlarvae was greater in the control and heterotrophic system than in the autotrophic in terms of weight gain and SGR. Growth in all three systems (51-82 $\mathrm{mg}$ in 28 days) was better than reported for nursing $L$. vannamei without Artemia, and similar to those using Artemia, whereas survival was similar. Final mean weight ranged 27.1-35.8 mg for postlarvae nursed 21 days without Artemia and 29.4$47.0 \mathrm{mg}$ for those nursed with Artemia while survival was $>65 \%$ (Zelaya et al., 2009). In contrast, survival was around $56 \%$ for Penaeus monodon nursed in a microalgae coatedbased system (Khatoon et al., 2009), much lower than recorded in our study. However, in these two studies, the postlarvae stocking density was higher. Also, our study was 28 days, while those of Zelaya et al. (2009) and Khatoon et al. (2009) were 21 and 19 days, respectively. The growth response of shrimp in the control and heterotrophic system was similar to experiments in which both Artemia and formulated feed were used.

The growth response of juveniles in the nursery is important; however, in some circumstances survival is more important. Nursing is frequently carried out while ponds are being prepared for stocking or being used for a first grow-out phase. Thus the postlarvae must be maintained in separate structures for a longer period and it is assumed that postlarvae have compensatory growth once released into the ponds, where there is more space, better water quality, and more feed (Wu and Dong, 2002).

The great microalgae biomass in the control and autotrophic system may have significantly contributed to the nutrition of the postlarvae, as suggested by the very low FCR $(<0.7)$. Microalgae are one of the most important food sources during shrimp larval 
stages and contribute to the nutrient supply for postlarvae and juveniles in estuaries (Muller-Feuga et al., 2003). The specific growth rate and survival of $P$. monodon postlarvae were significantly higher in ponds where three microalgae (Amphora, Navicula, Cymbella) were grown on substrates (Khatoon et al., 2009). Microalgae are consumed by shrimp in the wild (Gleason and Zimmerman, 1984; Gleason and Wellington, 1988) and in aquaculture ponds (Hunter et al., 1987; Bombeo-Tuburan et al., 1993; Moss and Pruder, 1995). Nevertheless, juveniles in the autotrophic treatment had a lower growth response than the control. This might be because the higher survival in the autotrophic system resulted in a higher density that might have affected the growth rate, particularly during the latter part of the trial when the biomass of the organisms had quintuplicated. High density negatively affects growth in Penaeus japonicus (Coman et al., 2004) and the crayfish Cambarellus montezumae (ArredondoFigueroa et al., 2010).

In the heterotrophic system, the postlarvae had other nutritional sources, mainly detritus on the tank bottoms, bacteria on the tank walls and substrates (plastic mesh), and wheat bran. The FCR was also quite low in this treatment, suggesting that the formulated feed was only part of the total ingested feed. The growth of the postlarvae in this treatment was as high as that obtained in the control. Likewise, heterotrophic bacteria, coccid and filamentous cyanobacteria, flagellate and ciliate protozoa, and rotifers colonized on flocculated matter were important food sources for postlarvae of pink shrimp, Farfantepenaeus paulensis, nursed in bioflocs-based systems with different protein levels (Ballester et al., 2010). Microbial biomass is an important contribution to the nutrition and feeding of shrimp at different stages (Burford et al., 2004b; Abreu et al., 2007; Silva et al., 2008). Moreover, heterotrophic bacteria can synthesize protein from organic carbon and inorganic nitrogen (Avnimelech, 1999). Thus, bacterial biofilms and bioflocs are a source of protein for shrimp. The postlarvae reared in the heterotrophic system had a successful productive response without consuming microalgae, suggesting that heterotrophic bacteria be studied as an alternative or complement to microalgae for postlarvae production.

Zero water exchange probably contributed to the low FCR in all treatments. Nutrients were not released in effluents, which favored the formation of nutrient cycling through the food chain. Nutrients are cycled in aquaculture systems in which microalgae or bacteria are present, especially those with a low or zero water exchange (Crispim et al., 2007; Jirsa et al., 2007; Avnimelech et al., 2008).

The results of this study support the feasibility of nursing $L$. vannamei in heterotrophic or autotrophic based systems without Artemia and with zero water exchange by promoting natural biota such as microalgae in autotrophic systems and bacteria in heterotrophic. A decrease or cessation in the use of Artemia for nursing postlarvae implies a decrease in the operative costs. Zero water exchange may also provide for nutrient recycling, thereby increasing the available protein in the system. Such systems are more bio secure and environmentally friendly because the introduction of pathogens is limited and the impact caused by effluents is eliminated.

\section{References}

Abreu P.C., Ballester E.L.C., Odebrecht C., Wasielesky W., Cavalli R.O., Graneli W. and A.M. Anesio, 2007. Importance of biofilm as food source for shrimp (Farfantepenaeus paulensis) evaluated by stable isotopes (d13C and d15N). J. Exp. Mar. Biol. Ecol., 347:88-96.

Arredondo-Figueroa J.L., Vasquez-Gonzalez A., Barriga-Sosa I., Carmona-Osalde C. and M. Rodríguez-Serna, 2010. Effect of density on growth and feeding of the crayfish Cambarellus montezumae (Saussure, 1857). J. Appl. Aquacult., 22:66-73.

Avnimelech Y., 1999. Carbon/nitrogen ratio as a control element in aquaculture systems. Aquaculture, 176:227-235.

Avnimelech Y., Verdegem M.C.J., Kurup M. and P. Keshavanath, 2008. Sustainable land-based aquaculture: rational utilization of water, land and feed resources. Medit. Aquacult. J., 1:45-55. 
Ballester E., Wasielesky W., Cavalli R., Santos M. and P. Abreu, 2003. Influência do biofilme no crescimento do camarão-rosa Farfantepenaeus paulensis em sistemas de berçário. Atlântica, 25:117-122.

Ballester E., Wasielesky W., Cavalli R., Santos M. and P. Abreu, 2007. Nursery of the pink shrimp Farfantepenaeus paulensis in cages with artificial substrates: biofilm composition and shrimp performance. Aquaculture, 265:355-362.

Ballester E.L.C., Abreu P.C., Cavalli R.O., Emerenciano M., Abrew L. and W. Wasielesky, 2010. Effect of practical diets with different protein levels on the performance of Farfantepenaeus paulensis juveniles nursed in zero water exchange suspended microbial flocs intensive system. Aquacult. Nutr., 16:163-172.

Bombeo-Tuburan I., Guanzon N.G. and G.L. Schroeder, 1993. Production of Penaeus monodon (Fabricius) using four natural food types in an extensive system. Aquaculture, 112:57-65.

Burford M.A., Thompson P.J., Mcintosh R.P., Bauman R.H. and D.C. Pearson, 2004a. The contribution of flocculated material to shrimp (Litopenaeus vannamei) nutrition in a high-intensity, zero exchange system. Aquaculture, 232:525-537.

Burford M.A., Sellars M.J., Arnold S.J., Crocos P.J. and N.P. Preston, 2004b. Contribution of natural biota associated with substrates to the nutritional requirements of the post-larval shrimp, $P$. esculentus (Haswell) in high-density rearing systems. Aquacult. Res., 35:508-515.

Coman G.J., Crocos P.J., Preston N.P. and D. Fielder, 2004. The effects of density on the growth and survival of different families of juvenile Penaeus japonicus Bate. Aquaculture, 229:215-223.

Crispim M.C., Vieira A.C.B., Coelho S.F.M. and A.M.A. Medeiros, 2007. Nutrient uptake efficiency by macrophyte and biofilm: practical strategies for small-scale fish farming. Biol. Limnol., 21:387-391.

Ebeling J.M., Timmons M. and J.J. Bisogni, 2006. Engineering analysis of the stoichiometry of photoautotrophic, autotrophic, and heterotrophic removal of ammonianitrogen in aquaculture systems. Aquaculture, 257:346-358.

Gleason D.F. and G.M. Wellington, 1988. Food resources of postlarval brown shrimp (Penaeus aztecus) in Texas salt marsh. Mar. Biol., 97:329-337.

Gleason D.F. and R.J. Zimmermann, 1984. Herbivory potential of postlarval brown shrimp associated with marshes. J. Exp. Biol. Ecol., 84:235-246.

Hunter B., Pruder G. and J. Wyban, 1987. Biochemical composition of pond biota, ingesta, and relative growth of Penaeus vannamei in earthen ponds. J. World Aquacult. Soc., 18:162-174.

Jirsa D.O., Davis D.A. and C.R. Arnold, 2007. Effects of dietary nutrient density on water quality and growth of red drum Sciaenops ocellatus in closed systems. J. World Aquacult. Soc., 28:68-78.

Khatoon H., Banerjee S., Yusoff F.M. and M. Shariff, 2009. Evaluation of indigenous marine periphytic Amphora, Navicula and Cymbella grown on substrates as feed supplement in Penaeus monodon postlarval hatchery system. Aquacult. Nutr., 15:186193.

Kuhn D.D., Lawrence A.L., Boardman G.D., Patnaik S., Marsh L. and G.J. Flick, 2010. Evaluation of two types of bioflocs derived from biological treatment of fish effluent as feed ingredients for Pacific white shrimp, Litopenaeus vannamei. Aquaculture, 303:2833.

Moss S.M. and G.D. Pruder, 1995. Characterization of organic particles associated with rapid growth in juvenile white shrimp, Penaeus vannamei Boone, reared under intensive culture conditions. J. Exp. Mar. Biol. Ecol., 187:175-191.

Muller-Feuga A., 2005. Microlagae for aquaculture. The current global situation and future trends. pp. 352-364. In: A. Richmond (ed.). Handbook of Microalgal Culture. Biotechnology and Applied Phycology. Blackwell Publ., USA.

Muller-Feuga A., Robert R., Cahu C., Robin J. and P. Divanach, 2003. Uses of microalgae in aquaculture. pp. 253-299. In: J.G. Støttrup, L.A. McEvoy (eds.). Live Feeds in Marine Aquaculture. Blackwell Publ. Co., Berlin. 
Quadros-Seiffert W. and L. Martinez-Cordova, 2008. Productividad Natural. Chapter II. In: C. Molina-Poveda, H. Villarreal (eds.). Estrategias de Alimentación en la Etapa de Engorde del Camarón. CYTED, La Paz, BCS, México. 110 pp.

Samocha T.M., Patnaik S., Speed M., Ali A.M., Burger J.M., Almeida R.V., Ayub Z., Harisanto M., Horowitz A. and D.L. Brock, 2007. Use of molasses as carbon source in limited discharge nursery and grow-out systems for Litopenaeus vannamei. Aquacult. Eng., 36:184-191.

Silva C.F., Ballester E., Monserrat J., Geracitano L., Wasielesky Jr. W. and P.C. Abreu, 2008. Contribution of microorganisms to the biofilm nutritional quality: protein and lipid contents. Aquacult. Nutr., 14:507-514.

Thompson F.L., Abreu P.C. and W. Wasielesky, 2000. Biofilms decrease the discharge of inorganic nutrients from Farfantepenaeus paulensis culture tanks. AQUA2000 Annu. Meeting World Aquacult. Soc., Eur. Aquacult. Soc., Book of Abstracts. 2-6 May 2000, Nice, France. 705 pp.

Wasielesky Jr. W., Atwood H., Stokes A. and C.L. Browdy, 2006. Effect of natural production in a zero exchange suspended microbial floc based super-intensive culture system for white shrimp Litopenaeus vannamei. Aquaculture, 258:396-403.

Wu L. and S. Dong, 2002. Compensatory growth responses in juvenile Chinese shrimp, Fenneropenaeus chinensis, at different temperatures. J. Crust. Biol., 22:511-520.

Zelaya O., Davis A. and D. Rouse, 2007. The influence of Artemia and algal supplements during the nursery phase of rearing Pacific white shrimp, Litopenaeus vannamei. J. World Aquacult. Soc., 38:486-496. 